American Journal of Infectious Diseases 2 (4): 197-200, 2006

ISSN 1553-6203

(C) 2006 Science Publications

\title{
Human Insulin Modulation of Escherichia coli Adherence and Chemotaxis
}

\author{
Karolina Klosowska and Balbina J. Plotkin \\ Department of Microbiology and Immunology, Midwestern University, Downers Grove, IL USA
}

\begin{abstract}
Escherichia coli exhibited increased hydrophobicity and mannose-resistant epithelial cell adherence after growth in the presence of human insulin $\left(2 \mu \mathrm{UL}^{-1}\right.$ or $200 \mu \mathrm{UmL}^{-1}$ insulin, respectively) with glucose $\left(100 \mathrm{mg} \mathrm{dL}^{-1}\right)$. Capsule production and hemagglutination were unaffected by insulin and glucose. Chemotactic attraction to glucose as compared to insulin or glucose alone was enhanced by the presence of insulin. Insulin alone $\left(200 \mu \mathrm{U} \mathrm{mL}^{-1}\right)$ was a chemorepellent and inhibited flagellar tethering to glass. These findings indicate that human insulin can modulate E. coli's expression of factors associated with pathogenesis in a manner that is modifiable by the presence of glucose.
\end{abstract}

Key words: Human insulin, uropathogenic E. coli, adherence, chemotaxis

\section{INTRODUCTION}

Escherichia coli is the most common etiologic agent of bacteremia, urinary tract infections (UTI) and acute pyelonephritis ${ }^{[1]}$. Any organism which causes systemic infections is exposed to a variety of host factors including hormones. The most prevalent and pervasive of these hormones is insulin. Previous studies determined that $E$. coli alters its growth kinetics in response to human insulin ${ }^{[2]}$. This insulin mediated change in doubling time is glucose dependent and reminiscent of quorum sensing, i.e., population size, dependent. However, other than affecting growth rates, insulin's effect on E. coli phenotype is unknown. The focus of this study was to determine the effect human insulin has on expression of factors reported to be associated with $E$. coli's ability to colonize, i.e., adherence-related colonization factors and motility.

\section{MATERIALS AND METHODS}

Bacterial isolates and growth conditions: $E$. coli ATCC 25923 a highly stable E. coli K12 routinely used for quality control testing was grown as previously described $^{[2]}$ in peptone $\left(1.0 \mathrm{gm} \mathrm{dL}^{-1}\right)$ yeast nitrogen base broth (PYNB) containing insulin at 2, 4, 20 and $200 \mu \mathrm{U} \mathrm{mL} \mathrm{m}^{-1}$ (Humulin $\AA$ R, Eli Lilly and Co., Indianapolis, $\mathrm{IN})$ and/or glucose $(0.1,0.5,1.0,2.0$ and 5 $\mathrm{gm} \mathrm{dL}^{-1}$ ) unless otherwise indicated.

Quorum sensing: Autoinducers I and II were measured as described by Surette et al. ${ }^{[3]}$ with Vibrio harveyi strains generously provided by Bonnie Bassler (Princeton University, NJ). Positive controls were filtrates from Vibrio harveyi $\mathrm{BB} 152$ and BB120 grown in medium with $\left(200 \mu \mathrm{U} \mathrm{mL}^{-1}\right)$ and without insulin and/or glucose $\left(0.2 \mathrm{gm} \mathrm{dL}^{-1}\right)$. E. coli were grown in
Mueller-Hinton broth containing insulin $\left(200 \mu \mathrm{U} \mathrm{mL}^{-1}\right)$ and/or $0.2 \mathrm{gm} \mathrm{dL}^{-1}$ glucose. Mid-log, early stationary and late stationary growth phase $(24 \mathrm{hr})$ cells were pelleted $(12,000 \mathrm{X} \mathrm{g}, 10 \mathrm{~min}, \mathrm{RT})$ and the supernatant filter sterilized then stored $\left(-70^{\circ} \mathrm{C}\right)$ until use. $V$. harveyi $\mathrm{BB} 170$ and $\mathrm{BB} 886\left(\mathrm{O} / \mathrm{N}\right.$ culture, $30^{\circ} \mathrm{C}, 1: 5 \times 10^{3}$ dilutions) luminescence (Coleman luminometer) was measured hourly after exposure to cell filtrate. Negative controls contained sterile medium.

Surface hydrophobicity: Surface hydrophobicity was determined as previously described ${ }^{[4]}$. E. coli were grown overnight $\left(37^{\circ} \mathrm{C}\right)$ in PYNB with and without insulin $\left(2,4,20\right.$ and $\left.200 \mu \mathrm{U} \mathrm{mL}^{-1}\right)$ and/or glucose $(0.1$, $0.5,1.0,2.0$ and $5.0 \mathrm{gm} \mathrm{dL}^{-1}$ ) in flat bottom tissue culture plates $\left(150 \mu \mathrm{L}\right.$ well $\left.{ }^{-1}\right)$. After careful washing (4X: PBS; $\mathrm{pH} 7.0$ ), the plates were air dried, stained with crystal violet $\left(50 \mathrm{ml} \mathrm{dL}^{-1} \mathrm{v} / \mathrm{v}\right.$ PBS; 20-30 min; $25^{0}$ C) and bacterial adherence to plastic measured (EIA reader, Dynatech Laboratories, Inc., Chantilly, Virginia; $590 \mathrm{~nm}$ ).

The production of acidic polysaccharide capsule was determined essentially as described for surface hydrophobicity $^{[4]}$ except that bacteria were stained with Alcian blue $\left(0.3 \mathrm{gm} \mathrm{dL} \mathrm{dL}^{-1} \mathrm{PBS}, 30 \mathrm{~min}\right.$, room temperature; EIA reader, Dynatech Laboratories, Inc., Chantilly, Virginia; $450 \mathrm{~nm}$ ).

Epithelial cell adherence: Human buccal and uroepithelial cells were obtained and stored until use as previously described ${ }^{[5-7]}$. The adherence assay was performed as described by Leffler et al. ${ }^{[8]}$. E. coli $\left(0.05, \mathrm{Abs}_{540 \mathrm{~nm}}\right)$ grown in Mueller-Hinton broth alone (growth control) or with insulin $\left(200 \mu \mathrm{U} \mathrm{mL}^{-1}\right)$ and/or $0.2 \mathrm{gm} \mathrm{dL}^{-1}$ glucose (St. Louis, MO) were washed and

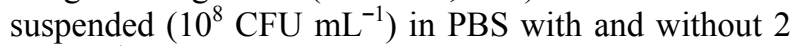
gm $\mathrm{dL}^{-1}$ mannose. One $\mathrm{ml}$ of bacterial suspension was

Corresponding Author: Balbina J. Plotkin, Ph.D., Department of Microbiology, Midwestern University, $55531^{\text {st }}$ St., Downers Grove, IL 60515, Tel: 630-515-6163, Fax: 630-515-7245 
mixed and incubated $\left(30 \mathrm{~min}, 37^{\circ} \mathrm{C}, 200 \mathrm{rpm}\right)$ with an equal volume of uroepithelial or buccal cells $\left(10^{5}\right.$ cells $\mathrm{mL}^{-1}$ ). The negative control was epithelial cells with 1 $\mathrm{ml}$ of PBS alone. After incubation, unattached bacteria were removed by centrifugation ( $250 \mathrm{X} \mathrm{g}, 10 \mathrm{~min}$; $4 \mathrm{X}$ ). The suspension was then dried, fixed and stained with crystal violet. The number of E. coli adherent to 50 epithelial cells assay ${ }^{-1}$ was counted.

Hemagglutination: Defibrinated sheep erythrocytes (Remel, Lenexa, KS) were washed twice in PBS and suspended to a final concentration of 0.5 cells $\mathrm{dL}^{-1}$. E. coli $\left(50 \mu \mathrm{L}^{-1}, 10^{10}\right.$ cells $\mathrm{mL}^{-1}$ PBS with and without 2 $\mathrm{gm} \mathrm{dL}^{-1}$ mannose) grown as described above for epithelial cell adherence were mixed with an equal volume of erythrocytes, then incubated at room temperature for 2-4 hours before reading ${ }^{[9]}$.

Chemotaxis: Chemotaxis was assessed essentially as described by Adler ${ }^{[10,11]}$ with the geotactic effects controlled by placement of capillary tubes in $5 \mathrm{ml}$ beakers containing $0.5 \mathrm{~mL}^{-1}$ of bacteria suspension instead of U-tubes. Mid-logarithmic growth phase cells $\left(37{ }^{\circ} \mathrm{C}\right.$, shaken; $\mathrm{OD}_{590}$ of 0.4$)$ were harvested by centrifugation at $6,0003 \mathrm{Xg}$ for $3 \mathrm{~min}$. The pellet was washed twice in chemotaxis medium $\left(10 \mathrm{mM} \mathrm{K}_{2} \mathrm{HPO}_{4}\right.$, $0.1 \mathrm{mM}$ EDTA) $\mathrm{pH} 7.0$ then adjusted to a final concentration of $7 \times 10^{6} \mathrm{CFU} \mathrm{mL}^{-1}$.

Analysis of free-swimming behavior: Swimming behavior of cells suspended in PYNB $\left(\mathrm{OD}_{590}\right.$ of 0.1$)$ with and without insulin and/or glucose, as described above, was assessed by bright-field microscopy (Petroff-Hauser counting chamber) and the extent of translocational movement and tail-spinning (flagellar tethering) determined.

Statistical evaluation: All assays were done in triplicate and repeated at least twice. Whenever possible, experiments were coded and performed in a blinded fashion. Analysis of variance was used to determine differences between experimental conditions with $P<0.05$ considered significant. If statistical significance was found, a Tukey-Kramer post-hoc analysis was applied (Instat, GraphPad Software, San Diego, CA).

\section{RESULTS AND DISCUSSION}

Human insulin in the presence of glucose affects expression of colonization factors. Insulin with glucose significantly $(P<0.05)$ enhanced adherence, biofilm formation and chemotactic response to glucose as compared to medium/buffer alone or medium/buffer with glucose (Table 1). The adherence to epithelial cells or erythrocytes was not affected by the presence of mannose. Microscopically, mid-logarithmic E. coli cells grown in insulin and glucose $\left(200 \mu \mathrm{U} \mathrm{mL} L^{-1}\right.$ insulin; $200 \mathrm{mg} \mathrm{dL}^{-1}$ glucose) were elongated, appeared tethered by their flagella to glass and exhibited clockwise and counterclockwise rotation $^{[12-14]}$. With the exception of chemorepulsion, insulin in the absence of glucose exhibited no other measurable effect on the virulence factors examined. Similar to the effects of insulin and glucose on growth rate ${ }^{[2]}$, the effects of insulin and glucose on virulence factor expression were concentration specific. Capsule production and hemagglutination were unaffected by the presence of insulin with or without glucose at all concentrations and combinations tested.

Some of the insulin effects measured may be due directly, or indirectly to the presence of homoserine lactone (AI-1) or cyclic borate diester (AI-2) which are autoinducers of quorum sensing and altered virulence factor production ${ }^{[3,15,16]}$. Addition of cell-free culture fluid of $E$. coli strains to either $V$. harveyi reporter strain BB170 (autoinducer-2) or BB 886 (autoinducer-1), showed no light production under conditions containing glucose and/or insulin indicating that under these growth conditions acyl-homoserine lactone autoinducers are not produced by E. coli.

Prior studies show that E. coli K12's microbial insulin has chemical, immunological and biological properties similar to that of mammalian, worm and protozoan insulin, although basic local alignment search tool (BLAST) analysis comparing human insulin and the E. coli genome indicated a lack of significant alignments which is not entirely surprising since human insulin is post-translationally processed ${ }^{[17-19]}$. In addition to affecting growth characteristics ${ }^{[2]}$, insulin with glucose also enhances adherence to epithelial cells, which is considered to be the first step in colonization of host mucosal surfaces. It is well documented that $E$. coli grown in medium with glucose exhibits an increased ability to adhere to uroepithelial cells ${ }^{[20]}$. Our findings indicate that insulin augments the effect of glucose thereby boosting epithelial cell adherence. This adherence may be mediated by a variety of adhesive factors $^{[20-27]}$ which are affected by insulin including fimbriae (P-pilus, because of mannose-resistance) and/or hydrophobic interactions. Microscopic examination of the motile cells also showed a tethering of cells to glass via their flagella in the presence of insulin and glucose but not insulin alone. Increased adherence to glass, a negatively charged surface, is reported to be indicative of ionic interactions and increased bacteria cell surface positive charge ${ }^{[28]}$. Increased positive surface charge has been correlated with an increased ability to interact with mammalian cell surfaces which carry a negative charge ${ }^{[29]}$. The tethering and rotational movement may also be reflective of localized changes in flagella composition resulting in electrostatic changes. However, while flagella have been reported to mediate adherence in enteropathogenic E. coli ${ }^{[30]}$ its role in E. coli $\mathrm{K} 12$ cellular adherence has not been established. 


\begin{tabular}{|c|c|c|c|}
\hline Virulence Factors & Media $^{\mathrm{a}}$ Control & $\begin{array}{l}\text { Media \& Glucose } \\
\left(100 \mathrm{mg} \mathrm{dL}^{-1}\right)\end{array}$ & $\begin{array}{l}\text { Media } \\
\text { Insulin }\end{array}$ \\
\hline Cell adherence ${ }^{c}$ & $10.1 \pm 0.26$ & $60.6 \pm 2.14^{\mathrm{e}}$ & $7.0 \pm 0$ \\
\hline Hydrophobicity & $5 \pm 0.2$ & $10.5 \pm 0.1^{\mathrm{e}}$ & $5.5 \pm 0$. \\
\hline Chemotaxis & $280 \pm 23$ & $710 \pm 56^{\mathrm{e}}$ & $81 \pm 5$ \\
\hline $\begin{array}{l}\text { a }- \text { PYNB and Mue } \\
\text { b-2, } 4,20 \text {, or } 200 \\
\text { c- number of } E \text {.co } \\
\text { d significantly diffe } \\
\text { e significantly diffe } \\
\text { f significantly diffe }\end{array}$ & $\begin{array}{l}\text { 1. All assays wer } \\
\text { lin } \\
\text { al cell } \pm \text { S.D. } \\
\text { glucose alone; } P \\
\text { media alone; } P< \\
\text { insulin alone; } P\end{array}$ & in triplicate and & \\
\hline
\end{tabular}

Flagella can also play another role in uropathogenesis. For Proteus mirabilis motility has been shown to contribute to virulence in ascending $\mathrm{UTIs}^{[31]}$. Whether motility and directional translocation play a similar role in the establishment of E. coli urinary infections remains to be determined. It is interesting that in the absence of glucose, an energy source, insulin acts as a chemo-repellent. However, in the presence of glucose insulin has the reverse effect, i.e., enhancing chemo-attraction to glucose. This effect of insulin on glucose chemotaxis indicates that the regulatory circuitry for glucose metabolism and chemotaxis may be more complex than previously thought ${ }^{[32]}$.

Based on the observations made in this study, human insulin appears to differentially regulate expression of virulence factors dependent on the presence of glucose. In the absence of glucose, insulin appears to act in a warning mode as a chemo-repellent seemingly signaling an inhospitable environment for colonization and promoting a planktonic population. In contrast, with glucose present insulin appears to signal a welcoming environment for colonization and long term survival by enhancing expression of adherence properties. This control of environmental adaptation would be crucial for environmental survival perhaps functioning through modulation of the $\mathrm{CsrA} / \mathrm{CsrB}$ and BarA/UvrY systems which are part of the glucosemediated regulatory circuitry for virulence factor expression, including biofilm formation ${ }^{[33]}$. The possible role this insulin-mediated switching of virulence factor expression plays in asymptomatic bacteriuria vs. the higher rate of urinary tract infections occurring in patients with type 2 diabetes and in females with gestational diabetes as compared to type 1 diabetics remains to be determined.

\section{ACKNOWLEDGMENT}

This study was funded by an intramural grant from Midwestern University. None of the authors have a commercial or other association that might pose a conflict of interest.

\section{REFERENCES}

1. Foxman, B., 2002. Epidemiology of urinary tract infections: Incidence, morbidity and economic costs. Am. J. Med., 113 (Suppl. 1A): 5S-13S.

2. Plotkin, B.J. and S.M. Viselli, 2000. Effect of insulin on microbial growth. Curr. Microbiol., 41: 60-4.

3. Hardie, K.R., C. Cooksley, A.D. Green and K. Winzer, 2003. Autoinducer 2 activity in Escherichia coli culture supernatants can be actively reduced despite maintenance of an active synthase, LuxS. Microbiol., 149: 715-28.

4. Farzam, F. and B.J. Plotkin, 2001. Effect of SubMICs of antibiotics on the hydrophobicity and production of acidic polysaccharide by Vibrio vulnificus. Chemotherapy, 47: 184-93.

5. Plotkin B. and D. Bemis, 1984. Adherence of Bordetella bronchiseptica to hamster lung fibroblasts. Infect. Immun., 46: 697-702.

6. Geerlings, S.E., R. Meiland and A.I. Hoepelman, 2002. Pathogenesis of bacteriuria in women with diabetes mellitus. Intl. J. Antimicrob. Agents, 19: 539-45.

7. Geerlings, S.E., R. Meiland, E.C. van Lith, E.C. Brouwer, W. Gaastra and A.I. Hoepelman, 2002. Adherence of type 1-fimbriated Escherichia coli to uroepithelial cells: more in diabetic women than in control subjects. Diabetes Care, 25: 1405-9.

8. Leffler, H. and C. Svanborg-Eden, 1981. Glycolipid receptors for uropathogenic Escherichia coli on human erythrocytes and uroepithelial cells. Infect. Immun., 34: 920-9.

9. Bemis, D.A. and B.J. Plotkin, 1982. Hemagglutination by Bordetella bronchiseptica. J Clin Microbiol, 15: 1120-7.

10. Adler, J., 1966. Chemotaxis in bacteria. Science, 153: 708-716.

11. Adler, J. and M.M. Dahl, 1967. A method for measuring the motility of bacteria and for comparing random and non-random motility. J. Gen. Microbiol., 46: 161-173.

12. Lux, R. and W. Shi, 2004. Chemotaxis-guided movements in bacteria. Crit. Rev. Oral Biol. Med., 15: 207-20. 
13. Szurmant, H. and G. Ordal, 2004. Diversity in chemotaxis mechanisms among the bacteria and archaea. Microbiol. Mol. Biol. Rev., 68: 301-19.

14. Silversmith, R. and R. Bourret, 1999. Throwing the switch in bacterial chemotaxis. Trends Microbiol., 7: 16-22.

15. Cloak, O.M., B.T. Solow, C.E. Briggs, C.Y. Chen and P.M. Fratamico, 2002. Quorum sensing and production of autoinducer-2 in Campylobacter spp., Escherichia coli O157:H7 and Salmonella enterica serovar Typhimurium in foods. Appl. Environ. Microbiol., 68: 4666-71.

16. Miller, M. and B. Bassler, 2001. Quorum sensing in bacteria. Annu. Rev. Microbiol., 55: 165-99.

17. LeRoith, D., J. Shiloach, J. Roth and M.A. Lesniak, 1981. Insulin or a closely related molecule is native to Escherichia coli. J. Biol. Chem., 256: 6533-6.

18. LeRoith, D., J. Shiloach, R. Heffron, C. Rubinovitz, R. Tanenbaum and J. Roth, 1985. Insulin-related material in microbes: similarities and differences from mammalian insulins. Can. J. Biochem. Cell Biol., 63: 839-49.

19. Dietz, E. and G. Uhlenbruck, 1989. An insulin receptor in microorganisms: Fact or Fiction? Naturwissensenschaften, 76: 269-270.

20. Geerlings, S.E., E.C. Brouwer, W. Gaastra, R. Stolk, R.J. Diepersloot and A.I. Hoepelman, 2001. Virulence factors of Escherichia coli isolated from urine of diabetic women with asymptomatic bacteriuria: correlation with clinical characteristics. Antonie Van Leeuwenhoek, 80: 119-27.

21. Anderson, G., J. Palermo, J. Schilling, R. Roth, J. Heuser and S. Hultgren, 2003. Intracellular bacterial biofilm-like pods in urinary tract infections. Science, 301: 105-7.

22. Jackson, D., K. Suzuki, L. Oakford, J. Simecka, M. Hart and T. Romeo, 2002. Biofilm formation and dispersal under the influence of the global regulator CsrA of Escherichia coli. J. Bacteriol., 184: 290301.

23. Jackson, D., J. Simecka and T. Romeo, 2002. Catabolite repression of Escherichia coli biofilm formation. J. Bacteriol., 184: 3406-10.
24. Agladze, K., D. Jackson and T. Romeo, 2003. Periodicity of cell attachment patterns during Escherichia coli biofilm development. J. Bacteriol., 185: 5632-8.

25. Wullt, B., G. Bergsten, M. Samuelsson, N. Gebretsadik, R. Hull and C. Svanborg, 2001. The role of $\mathrm{P}$ fimbriae for colonization and host response induction in the human urinary tract. $\mathrm{J}$. Infect. Dis., 183 (Suppl. 1): S43-6.

26. Miyazaki, J., W. Ba-Thein, T. Kumao, M. Obata Yasuoka, H. Akaza and H. Hayshi, 2002. Type 1, P and $\mathrm{S}$ fimbriae and afimbrial adhesin I are not essential for uropathogenic Escherichia coli to adhere to and invade bladder epithelial cells. FEMS Immunol. Med. Microbiol., 33: 23-6.

27. Jacobson, S.H., C. Ostenson, K. Tullus and A. Brauner, 1992. Serum resistance in Escherichia coli strains causing acute pyelonephritis and bacteraemia. APMIS, 100: 147-53.

28. Gross, M., S. Cramton, F. Gotz, A. Peschel, 2001. Key role of teichoic acid net charge in Staphylococcus aureus colonization of artificial surfaces. Infect. Immun., 69: 3423-6.

29. Healy, K., B. Lom and P. Hockberger, 2004. Spatial distribution of mammalian cells dictated by material surface chemistry. Biotechnol. Bioengin., 43: $792-800$.

30. Giron, J., A. Torres, E. Freer and J. Kaper, 2002. The flagella of enteropathogenic Escherichia coli mediate adherence to epithelial cells. Molec. Microbiol., 44: 361-79.

31. Emody, L., M. Kerenyi and G. Nagy, 2003. Virulence factors of uropathogenic Escherichia coli. Intl. J. Antimicrob. Agents, 22: S29-S33.

32. Taylor, B. and I. Zhulin, 1998. In search of higher energy: metabolism-dependent behavior in bacteria. Molec. Microbiol., 28: 683-690.

33. Suzuki, K., X. Wang, T. Weilbacher, A. Pernestig, D. Georgellis, P. Babitzke and T. Romeo, 2002. Regulatory circuitry of the $\mathrm{Csr} A / \mathrm{CsrB}$ and BarA/UvrY systems of Escherichia coli. J. Bacteriol., 184: 5130-5140. 